\title{
The Influences of Institutional Logics Dynamics on Organizational History: the Case of Veiling Holambra Cooperative
}

\author{
Maisa Gomide Teixeira ${ }^{\dagger}$ \\ Universidade Federal do Mato Grosso do Sul - UFMS \\ Karina De Dea Roglio ${ }^{\Omega}$ \\ Universidade Federal do Paraná - UFPR
}

\begin{abstract}
The objective of this paper is to analyze the influences of institutional logics dynamics on the decisions about structural changes adopted by an agricultural cooperative. The literature review was based on the concept of institutional logics and on some peculiarities of the administration of cooperative organizations. We argue that these organizations are hybrids and, as such, report to institutional complexity adopting practices and beliefs consistent with characteristics of more than one institutional logic. In this sense, we draw upon an empirical study, based on a qualitative case study and oral history at Veiling Holambra Cooperative. The field work relied on semi structured interviews, non-participant observations and document analysis. Thus it was possible to identify in the history of the cooperative, from 1948 to 2011, elements that relate to different institutional logics. The paper reinforces logics as non- excludent and contributes for a better understanding of the hybridism phenomenon in organizations. Furthermore, it provides conditions for organizations to revaluate the apparent contradiction between practices with a social purpose and market oriented practices.
\end{abstract}

Keywords: Organizational institutionalism. Institutional logics. Cooperatives. Hybridism.

${ }^{*}$ Doctor at the Universidade Federal do Parana Type of contract: Guest Professor at the Universidade Federal do Mato Grosso do Sul

Address: Av. Senador Filinto Muller. Cidade

Universitária. Campo Grande - MS - Brazil

Phone: (67) 8117-1666

\footnotetext{
${ }^{\Omega}$ Doctor at the Universidade Federal de Santa Catarina

Type of Contract: Professor at the Universidade Federal do Paraná Address: Av. Prefeito Lothário Meissner - 632. Curitiba - PR - Brazil Email: karinaroglio@gmail.com Phone: (41)3360-4365
} 


\section{INTRODUCTION}

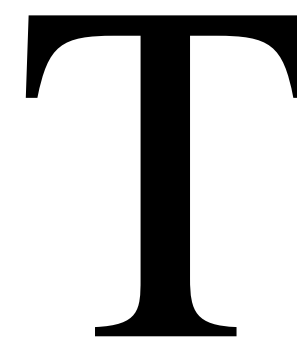

he research reported in this paper has the objective to analyze the influences of institutional logics dynamics on the decisions about structural changes at Veiling Holambra Cooperative, from 1948 to 2011. The analysis of organizational trajectory shows the mobilization of the actors to push through their interests in decisions relating to the adoption of changes in the cooperative structure. In this way, the organization faced three crises, in 1952, 1986 and 1995, identified as milestones related to decisions on structural change. To comprehend these decisions, we used the institutional logic approach in order to understand the organizational field dynamics, allowing the integrated analysis of organizations' behavior in relation to societal structures. Thus, considerations on effects on mini or micro level can be linked to macro level changes without, for that, adopt a perspective of uniformity and organizational homogeneity, as is assumed in isomorphic organizational models .

Referring to the perspective of uniformity, Greenwood, Suddaby and Hinings (2002) explain that the literature on institutional studies had more consideration with field dynamics that, as organizational responses to regulatory pressures, manifested in similar ways. Therefore, only the knowledge about a type of dynamic effect field increased, while the unveiling on how and why the isomorphic effects emerge remained unexplored. The authors point out, therefore, the importance of the institutionalism studies of transition from a focus on convergent change to another, as it considers non isomorphic processes that occur in contexts, since the notion of structure which involves the establishment and gradual specification of roles, behaviors and interactions does not imply perfect reproduction.

The concept of institutional logics is conceived in what it says about the variety of guidelines that are legitimate according to the spatial-temporal context. The social reality is considered wrapped into multiple logical, conflicting or not, that can be combined and worked by actors (FRIEDLAND; ALFORD, 1991), in order to raise provisions that do not reflect the mere reproduction of the structural conditions. In this sense, Thornton and Ocasio (2008) propose that the contradictions inherent to the set of institutional logics provide to individuals, groups and organizations the cultural resources to transform identities, organizations and society itself. This is one of the institutional change assumptions that come from the concept of institutional logics. 
The reference to the institutional logics makes the concept of institutional complexity essential to an understanding of the organizational phenomena. This concept, according to Kraatz and Block (2008), has as principle that, although the organizations confront and are conditioned by institutions, the institutional systems are not necessarily unified or coherent. Organizations are immersed in contexts with multiple institutional tensions which, as create conditions for fragmentation and conflict, allow the existence of different forms of organizational arrangements.

Thus, the field of cooperative organizations is as an exciting field for analysis. During the 1990s, hovered over Brazilian cooperatives the shadow of administrative inefficiency and low productivity that conflicted with the new global competition model that came to be followed in country with the trade opening. Trade liberalization made the cooperatives face severe difficulties. There were cases of coopertarive dissolutions, as the Cooperativa Agrícola Cotia. However, with the identity and strategies changes, gradually, the system restructured and cooperative organizations have dawned in many economic sectors.

This transition, however, threatened the image of the cooperatives as a third way for economic development and moving them toward models strongly marked by economic behavior. The cooperative was considered as third way for a long time after its creation, having been developed in parallel with the great economic doctrines providing an alternative line for social development, preserving from the capitalism the idea of profit and private property, and from socialism, solidarity and a sense of social justice (MELO, 2011). Some studies (e.g. Saraiva, 2010; Taylor 1994) describe changes showing that the institutional environment of cooperatives develops under an increasing influence of the market institutional logic, which has a number of implications in terms of administrative practices and standards adopted by these organizations. However, taking into account its dual nature, historically conditioned, it is argued that the restructuring process in cooperatives do not happen directly as an inexorable course, which suggests that motivations, interests and intersubjective values are supported in different institutional logics, conditioning conflicts in decisions and strategies of the organization. Under this view, the restructuring of cooperative organizations can be conceived as a multifaceted phenomenon.

Thus, this study contributes to organizational institutionalism when exploring the analytical possibilities of the intra organizational approach, which was being relegated in favor of macro tests, as suggested by Kirschbaum (2010). The author states that not in spite of the impact of DiMaggio's (1991) work, which calls for more attention to micro and meso 
aspects to advance the neo-institutionalism, it sees little effort in this direction. Studies of this nature are those that can effectively connect the managers sense of action with the organization institutional dynamics (KIRSCHBAUM, 2010).

This article was structured to include, after this introduction, theoretical elements that support the arguments presented here, followed by the methodological procedures for the conduct of the filed study and then it proceeds to the analysis section and discussion of the data. It closes presenting the findings, the practical implications of the study and suggestions for future research.

\section{INSTITUTIONAL LOGICS AND COOPERATIVE ORGANIZATIONS}

The institutional logics conceptemerged from Friedland and Alford (1991) ideas. The authors named institutional logic "the set of material practices and symbolic constructions which constitutes the organizational principles of an institutional system and provides explanatory vocabularies of reasons and a sense of 'self' to the social actors" (p. 248) The institutional orders which are the source logic that provide guidance for the Western society are: the capitalism, the state, the democracy, family, religion and science (FRIEDLAND; ALFORD, 1991). According to these authors, the institutional logics provide the larger context for the defense that occurs at the organizational level. Since the fact that they operate simultaneously in multiple institutional contexts, individuals are subject to multiple logics. The "contradictions" that exist between the institutional logics are highlighted by the authors for providing opportunities for the agency at the organizational level. "The institutional contradictions are the basis of the most important political conflicts of our society, it is through these conflicts that the institutional structure of society is transformed "(FRIEDLAND; ALFORD, 1991, p. 256).

In the view of Thornton (2004), Thornton, Jones and Kury (2005), Thornton and Ocasio (2008), the main sectors or society orders that influence the institutional and organizational arrangements of Western society are: market, corporations, professions, State, families and religions, as shown in Table 1. As the use of the institutional logics premises became increasingly frequent in the institutionalist research, the consensus regarding the implications of the institutional logics on decisions about the adoption of practices and organizational structures became notorious. So the question of the universality of the assumption of economic rationality instilled by Thornton (2002) gained force. The author states that "although economic forces impinge on organizations, how actors interpret the meaning and 
The Influences of Institutional Logics Dynamics on Organizational History:

the Case of Veiling Holambra Cooperative

the consequences of those economic forces is contingent on higher-order institutional logics" (p. 82).

Table 1 - Institutional Logics of Societal Sectors

\begin{tabular}{|c|c|c|c|c|c|c|}
\hline Characteristic & Market & Corporations & Professions & State & Families & Religions \\
\hline $\begin{array}{c}\text { Economic } \\
\text { system }\end{array}$ & $\begin{array}{l}\text { Investor } \\
\text { Capitalism }\end{array}$ & $\begin{array}{l}\text { Managerial } \\
\text { capitalism }\end{array}$ & $\begin{array}{l}\text { Personal } \\
\text { Capitalism }\end{array}$ & $\begin{array}{l}\text { Collective } \\
\text { welfare }\end{array}$ & $\begin{array}{l}\text { Personal } \\
\text { Capitalism }\end{array}$ & $\begin{array}{l}\text { Western } \\
\text { capitalism }\end{array}$ \\
\hline $\begin{array}{c}\text { Symbolic } \\
\text { analogy effect }\end{array}$ & $\begin{array}{l}\text { Market as } \\
\text { transaction }\end{array}$ & $\begin{array}{l}\text { Hierarchy as a } \\
\text { corporation }\end{array}$ & $\begin{array}{l}\text { Professions } \\
\text { as a network }\end{array}$ & $\begin{array}{l}\text { State as a } \\
\text { redistribution } \\
\text { mechanism }\end{array}$ & $\begin{array}{l}\text { Family as } \\
\text { firm }\end{array}$ & Temple as bank \\
\hline $\begin{array}{l}\text { Sources of } \\
\text { identity }\end{array}$ & Faceless & $\begin{array}{l}\text { Bureaucratic } \\
\text { roles / quantity } \\
\text { production }\end{array}$ & $\begin{array}{l}\text { Personal } \\
\text { reputation / } \\
\text { quality of } \\
\text { innovation }\end{array}$ & $\begin{array}{l}\text { Political } \\
\text { ideology of } \\
\text { social class }\end{array}$ & $\begin{array}{l}\text { Family } \\
\text { reputation / } \\
\text { father and } \\
\text { son } \\
\text { relationships }\end{array}$ & $\begin{array}{l}\text { Occupational } \\
\text { and vocational } \\
\text { Association } \\
\text { with deities }\end{array}$ \\
\hline $\begin{array}{l}\text { Sources of } \\
\text { legitimacy }\end{array}$ & Share's price & $\begin{array}{l}\text { Market position } \\
\text { of the company }\end{array}$ & $\begin{array}{l}\text { Personal } \\
\text { expertise }\end{array}$ & $\begin{array}{l}\text { Democratic } \\
\text { Participation }\end{array}$ & $\begin{array}{l}\text { Loyalty } \\
\text { unconditional }\end{array}$ & $\begin{array}{l}\text { Evocation } \\
\text { supernatural }\end{array}$ \\
\hline $\begin{array}{l}\text { Sources of } \\
\text { authority }\end{array}$ & $\begin{array}{l}\text { Activism } \\
\text { shareholder }\end{array}$ & $\begin{array}{l}\text { Board of } \\
\text { directors / } \\
\text { management }\end{array}$ & $\begin{array}{l}\text { Professional } \\
\text { Associations }\end{array}$ & $\begin{array}{l}\text { Bureaucratic } \\
\text { domination / } \\
\text { political } \\
\text { parties }\end{array}$ & $\begin{array}{l}\text { Patriarchal } \\
\text { domination }\end{array}$ & $\begin{array}{l}\text { Personal } \\
\text { charisma of the } \\
\text { prophet / power } \\
\text { and status of } \\
\text { the priesthood }\end{array}$ \\
\hline $\begin{array}{c}\text { Base } \\
\text { strategies: } \\
\text { increase of ... }\end{array}$ & $\begin{array}{l}\text { Efficiency of } \\
\text { transactions }\end{array}$ & $\begin{array}{l}\text { Size and } \\
\text { diversification } \\
\text { of the firm }\end{array}$ & $\begin{array}{l}\text { Reputation / } \\
\text { quality craft }\end{array}$ & $\begin{array}{l}\text { Collective } \\
\text { good }\end{array}$ & $\begin{array}{l}\text { Honor, } \\
\text { security and } \\
\text { family } \\
\text { solidarity }\end{array}$ & $\begin{array}{l}\text { Supernatural } \\
\text { symbolism of } \\
\text { natural events }\end{array}$ \\
\hline $\begin{array}{c}\text { Informal } \\
\text { mechanisms } \\
\text { of control } \\
\end{array}$ & $\begin{array}{c}\text { Analysis of } \\
\text { the industrial } \\
\text { segment } \\
\end{array}$ & $\begin{array}{c}\text { Organizational } \\
\text { culture }\end{array}$ & $\begin{array}{c}\text { Professional } \\
\text { celebrity }\end{array}$ & $\begin{array}{c}\text { Policy } \\
\text { Backstage }\end{array}$ & $\begin{array}{l}\text { Family } \\
\text { policy }\end{array}$ & Worship \\
\hline $\begin{array}{c}\text { Formal } \\
\text { mechanisms } \\
\text { of control }\end{array}$ & $\begin{array}{c}\text { Imposition } \\
\text { of regulation }\end{array}$ & $\begin{array}{c}\text { Authority of the } \\
\text { board and } \\
\text { management }\end{array}$ & $\begin{array}{l}\text { Internal / } \\
\text { external } \\
\text { supervision }\end{array}$ & $\begin{array}{c}\text { Imposition of } \\
\text { legislation }\end{array}$ & $\begin{array}{l}\text { Inheritance } \\
\text { rules and } \\
\text { succession }\end{array}$ & $\begin{array}{c}\text { Rationalization } \\
\text { of usury / } \\
\text { taboos } \\
\text { standards }\end{array}$ \\
\hline $\begin{array}{c}\text { Organizational } \\
\text { form }\end{array}$ & Market & M-Form & $\begin{array}{l}\text { Network } \\
\text { organization }\end{array}$ & $\begin{array}{l}\text { Legal } \\
\text { Bureaucracy }\end{array}$ & $\begin{array}{l}\text { Family } \\
\text { Partnership }\end{array}$ & $\begin{array}{l}\text { Religious } \\
\text { congregation }\end{array}$ \\
\hline $\begin{array}{c}\text { Logic } \\
\text { investment }\end{array}$ & $\begin{array}{l}\text { Capital } \\
\text { committed } \\
\text { to the capital } \\
\text { market }\end{array}$ & $\begin{array}{l}\text { Capital } \\
\text { committed to } \\
\text { corporation }\end{array}$ & $\begin{array}{l}\text { Capital } \\
\text { committed to } \\
\text { the } \\
\text { relationship } \\
\text { link }\end{array}$ & $\begin{array}{l}\text { Capital } \\
\text { committed to } \\
\text { public policy }\end{array}$ & $\begin{array}{l}\text { Capital } \\
\text { committed to } \\
\text { home }\end{array}$ & $\begin{array}{l}\text { Capital } \\
\text { committed to } \\
\text { salvation }\end{array}$ \\
\hline
\end{tabular}

Source: Based on Thornton (2004, p. 44), Thornton, Jones and Kury (2005, p.168).

Each societal sector has a central logic that reinforces the organizing principle of the sectors. In turn, these logics articulate "the vocabularies of motives, the logic of action and the sense of self in specific societal sectors" (THORNTON, 2004, p. 42). Although all organizations are full of economic, political and socio-psychological interests, Thornton (2004) claims that their sources, their meanings and their focus of attention are conditioned by higher order institutional logics.

To demonstrate the effect of institutional logics, Thornton (2004) presents Table 1, in which she explains the key-elements from taxonomy ideal type for each of the societal sectors. The author states that institutional logics refer to the taxonomies of the basic 
institutions in Western society, each with its own axial principle and associated routines and rituals. Consequently, the logical constraints on an interpretation and vision of archetypal governance organizational structures and mechanisms used to coordinate economic activity, as part of a range of institutions in society. In this sense, the contents of the cells in the table are representing the supposed characteristics in a given element if, hypothetically, the logic of a sector manifested itself in its genuine form.

Logics have been described primarily in terms of cognitive cultural elements (SCOTT, 2004, p. 22; SCOTT, 2008, p. 187). Scott (2008) comments that the attention to the cultural aspects of organizational fields was for a long time in the background. There was a clear predominance of the relational approaches in the field. However, the publication of Friedland and Alford (1991) paper changed this scenario . These authors, as Scott (2008), have made progress in developing more deep cultural/cognitive systems which motivated and permeated some of the most important struggles between groups, organizations and classes (struggles, for example, on the most appropriate relationships between institutions on which institutional logic should regulate different activities, or on which type of logic would apply better to every kind of person).

It can be assumed, therefore, that: while the concept of institution covers regulative, normative and cognitive dimensions, usually in the midst of the borders of the organizational field, institutional logics are based on cultural aspects - that cognitive normally intersect the fields of activity. The institutions' cultural-cognitive dimension stands out only from the organizational institutionalism when it comes to represent its most distinctive feature. The hyphen in the label 'cultural-cognitive', Scott (2008) explains, would be for the acknowledgment that internal interpretative processes are profiled by external cultural references.

In this cultural - cognitive institutional pillar, the emphasis is on the shared conceptions that constitute the nature of social reality and the model (frame), by which meaning is accessed. This implies that, for understanding aspects supported by the cultural - cognitive pillar, the notion of intersubjectivity, is essential. Cultural sign facets are treated as symbolic systems, perceived as external and objectives to individual actors, while the internal representation of the environment and the activity is through the meanings that, in turn, are made up of symbols. Therefore, to understand and explain any action it must consider not only their objective conditions, but the subjective interpretation that the actor does of this 
action, which emphasizes the role played by the shared meanings socially constructed (Scott, 2008).

According to Kraatz and Block (2008) some insights and images criticisms can be attributed to the joint approach of cognitive institutionalism and institutional pluralism. Specifically, the authors argue that we are able to envision an organization that can have multiple identities institutionally specified and therefore "an organization may be the structural embodiment or incarnation of multiple logic, an organization that can be legitimized by multiple mythologies and an organization wherein very different beliefs and values might be simultaneously taken for granted "(p. 244 ). In this sense, Lounsbury (2007) explains that the foundation for the conflict and continuous change comes from multiple types of historically rooted belief systems and therefore competing institutional logics favor the variation in practices and behavior of different groups of actors.

According to the institutional theoretical references used in this study, organizational change is usually concpetualized as a result of external pressures. However this concept was harshly criticized and led to a new approach, in which the endogenous change also received attention. The endogenous change modelsgained support from the development of works in the institutional logic field. This conceives the possibility of heterogeneity and variability in response to institutional pressures. The plurality of orientations, the conflicts and ambiguities enhance more opportunities to the actors than it was assumed, and thus the change implicated in institutional logic processes does not feature a uniquely exogenous movement, and also does not represent an endogenous trend, but a co-evolutionary one. Social actors, supported by institutional logics, are the organizers of the pressures for change. Figure 1 is intended to outline the complexity of co-evolutionary social processes.

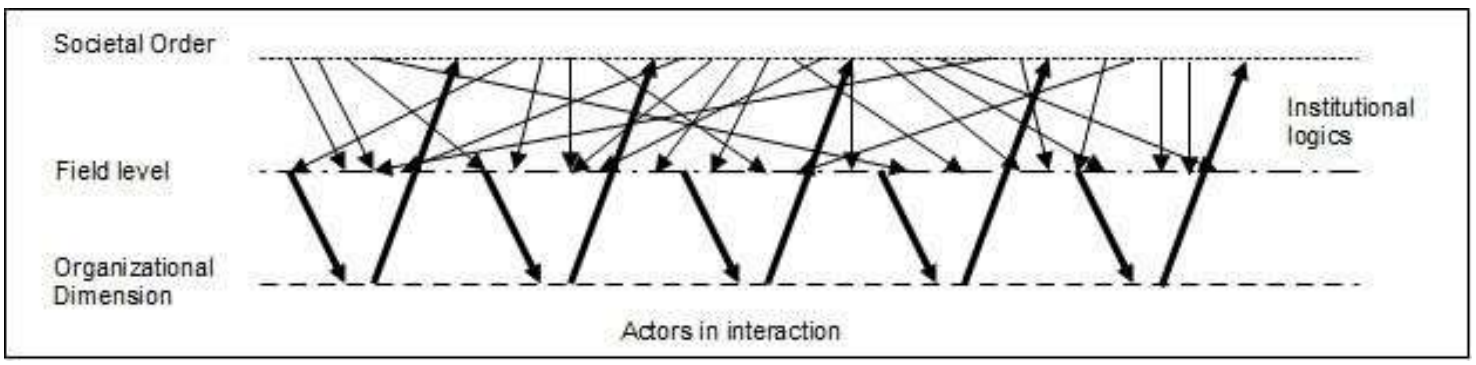

Figure 1: Complexity of changing processes involved in institutional logic transitions. Source: Teixeira (2012)

The line at the upper end represents the different societal orders or basic institutions, identified by Friedland and Alford (1991), which form the Western society. Each one is associated with a separate institutional logic and hence with respective meaning and 
normative understandings systems. According to Nigan and Ocasio (2010), multiple logics can interact and compete for influence in all institutional domains. Thus, Teixeira (2012) explains that no institutional logical fields, which serve as reference for organizational performance, have different importance. While the organizational practices and structures represent tangible manifestations of logic, when combined and configured on a recurring basis over time, they provide feedback to the societal domain.

Based on these concepts, Cooperatives are considered as an exciting object of analysis. The hybrid nature of these organizations and the changes they are going through indicating a recovery of institutional logics arrangement are emphasized in this regard.

Schneider's work (1999) shows that the cooperative ideas was created along with the labor movement of the nineteenth century, which sought to overcome the adversities imposed by the capitalist model. With the cooperative organizations, it was wanted to provide alternative forms of work from those found in capitalist companies, emphasizing a different social environment to give greater dignity to the worker. It was believed, according to the author, that the creation and multiplication of cooperatives could be an instrument to alleviate the dependency situations and capitalist exploitation of the proletariat. Thus, while they sought different working conditions, not wanting to break with capitalism, but providing means for workers also take advantage of the system. Therefore, according to the concept of hybrid organizations given by D'Aunno, Sutton and Price (1991), cooperative fall into this description.

Hybrid organizations, to D'Aunno, Sutton and Price (1991), are those that adopt consistent practices and beliefs with characteristics of more than one institutional environment. For the authors, organizations have difficulty to adapt to fragmented environments with differing values and conflicting beliefs on appropriate behaviors and structures. And, because of this limitation in response ability to conflicting demands, it only partially conforms to them. The assumptions based on this definition are of Meyer and Rowan (1977, p. 356) that realized that organizations take a lot of risks, having to choose between different beliefs in which they will adopt internally consistent practices. Therefore, they incorporate various types of incompatible structural elements seeking external support. The central argument in the work of D'Aunno, Sutton and Price (1991) is the increasing penetration of inter-institutional contradictions in the daily practices of contemporary organizations. Conflicts in the institutional environment were being mapped in the structure and practices of these organizations. 
In cooperatives, the dual dimension encompassed by the organization is explained by Bialoskorski (2002) which highlights, in terms of market, the economic logic of maximizing returns, competition and prices. On the other hand, the corporate vision stands for elevation of the associated 's wealth, valuing the contractual loyalty, solidarity and business ethics, transparency and the development of all those involved with equitable distribution of results. The cooperative principles, maintained as a criterion for membership by the International Cooperative Alliance (ICA), aim the coexistence of these two dimensions in cooperatives. For Schneider (1999, p.49), they represent the values "that illuminate and guide the experience of any cooperative" and identify the typical face of this type of organization anywhere in the world. Despite the possibility of adaptation to the peculiarities of each region, continues this author, "in essence, cooperatives shall seek to be free organizations, autonomous, inspired by self-help and by the predominance of the process of cooperation over competition" (SCHNEIDER, 1999, p. 49).

On recent decades, the challenge imposed by the capitalist society had been particularly difficult for cooperatives. In Brazil, with trade liberalization in the 1990s, cooperatives faced severe difficulties, but are now suited and have expanded in many economic sectors. It is claimed that this moment has represented the transition to a new arrangement of institutional logics in the field of cooperative organizations. The new guidance would imply increased employment practices and structures with more features consistent with societal sectors of the market and corporation (TAYLOR, 1994; SARAIVA, 2010) and the distance of beliefs and organizational forms with characteristics pertaining to State sectors, professions and family (see Table 1).

As examples of structural changes resulting from logical hybridity in cooperatives, we can cite the work of Saraiva (2010) and Taylor (1994). Saraiva (2010) identified in the cooperative credit sector changes relating to the employment practices with more capitalist banking organizations characteristics. Among these practices, the author cites the vertical organizational structure, the emphasis on growth and profitability, efficiency, measured by return on capital and for the market share, the associated loyalty techniques and interest in the internationalization of business, through partnerships. In the agricultural sector, Taylor (1994) pointed out that the new scenario implied in the collapse of collective goals to a lower level in the considerations of organizational decision making. As a result, the provision of services to small producers and the reduction of social inequality are no longer targeted and it began to 
favor the promotion of agricultural production in the industrial style (agribusiness), to admit incentives to executives and to increase the focus on centralized management.

Claiming that the transition to a new orientation of logic in the field of cooperative organizations was being portrayed through direct and simple transfer of strategic management approaches, Jäger and Beyes (2010) suggest caution. Notwithstanding the merit to demonstrate the cooperatives' progressive movement to a model in which economic rationality prevails, the authors warn that rationality shifts in hybrid organizations must be analyzed through observing the background of the particularities of these organizations. The positioning of the authors, in this sense, converges with the hybridity proposal of institutional logics.

Rao, Monin and Durand (2003) describe hybridization and the institutional setting through bottom-up process in which the traditional identity is not completely replaced. Glynn and Lounsbury (2005) report that despite the merger of institutional logics in some behavioral dimensions, other dimensions remain unchanged. This would have implications, according to Rao, Monin and Durand (2003), in decision-making process of organizations that must try to reconcile the new demands that comes from the environment and the traditional identity of the organization.

Thus, Haveman and Rao (2006) propose that hybridity has also a significatn role in organizations remodeling process, through the integration of new facets, whereas it preserves aspects of its history and its ideology. It is worth noting that, in spite of these authors explicitly relate hybridity to organizational change, it integrate elements of persistence and stability in its assessment of the phenomenon when proposing the retention of traditional elements as a result of the hybridization process. The possibility of considering change and stability in an inclusive manner, as potentially compatible in hybrid analysis allows embracing the alternative design proposed by Farjoun (2010) of stability and change as duality. With this perspective, the author wishes to break with the dichotomy of assumptions of the dualistic models expressed, for example, on punctuated equilibrium models.

According to Romanelli and Tushman (1994), giving this change, organizations evolve for relatively long periods of stability in their basic patterns of activity until they are driven by fundamental change triggers in relatively short periods. With no concussions, changes would present only incrementally, because there are several restrictions: durability of the institutions, pressures of actors with interests in maintaining the status quo, etc. In this study, rather than considering radical and incremental forms of change with temporally separate instances, 
similar to episodes of punctuated equilibrium models, the option is to see them as Farjoun (2010) suggests, mutually reinforcing.

Comprehending how organizations manage the conflict through hybridity, as highlighted by Thornton, Jones and Kury (2005, p. 162), stands as an important direction for research. This study is related to this issue, analyzing the influence of institutional logics dynamics in the changes in the organizational structure of an agricultural cooperative organization, the Veiling Holambra.

\section{METHODOLOGY}

A qualitative case study was conducted to analyze, through oral history, the influences of institutional logics in organizational trajectory from 1948 to 2011. From the institutional logics approach, the changes occurring in the organization were analyzed by adopting new organizational structures and the mobilization of actors to enter these structures in the cooperative. The research was conducted in 2011 in the Cooperativa Veiling Holambra $(\mathrm{CVH})$, with characteristics that justify the choice of a single case. First, the purpose and the conditions of its foundation and the initial characteristics of the organization consistent with the cooperative doctrine, promote the case as being particularly representative or "typical". CVH is today the largest flowers and plants sales center in Brazil, accounting for about $45 \%$ of the domestic market (VEILING HOLAMBRA, 2011). In recent years, it has adopted a bold management structures upgrade. Creswell (2007), in such cases, judges appropriate the choice for uniqueness.

The method adopted in this case study is instrumental, according to the typology of Stake (2000), i.e., the case does not specifically constitute the subject of the survey; however it is useful for developing theoretical proposals. Thus, the case itself is of secondary interest, but important to the understanding of other phenomenon: the institutional logics, its influence in decision-making and organizational changes. The field research was based on the method of oral history. In this kind of research, in accordance to Joutard (2005), historical knowledge is an element without which the organizational reality could not be understood in its essence. Thus, we adopted a cross-sectional with a longitudinal perspective, being the level of organizational analysis and the units of analysis the decision makers.

In order to preserve the validity of a qualitative research, we used the triangulation strategies and thick description, proposed by Creswell (2007). Regarding the strategy of triangulation, data were obtained from different cooperative members (directors, managers, elected cooperative members and cooperative members), which enabled the analysis of 
different experiences with the phenomenon investigated. Another procedure for enhancing the benefits of triangulation was the use of different data sources: document analysis, interviews and non-participant observation. We read carefully the data produced from these sources, aiming to categorize and understand the links among them. The comparison of data obtained from these materials contributed to the analysis, enabling to confirm the information collected and providing a more complete vision of the phenomenon.

The documents consisted of six historical works that referred to the cooperative or the city of Holambra: a book released on the fiftieth anniversary of Holambra, celebrated in 1998; a copy of the commemorative magazine after 60 years of Dutch immigration to Holambra, published in 2008 (SAMENWERKING, 2008); book that tells the story of a family of Dutch immigrants who participated in the initial activities of the cooperative; book on the story of a former director of the influential cooperative since its inception (BROEK, 2008); historical research published in a book that portrays the Dutch immigration experience (CORREA, 2011); monograph of a former president of the cooperative, which reports all the history of the organization until 2003 (RIETJENS, 2003). As there is not much literature on this subject, all that we found was considered in the analysis. In the process of document analysis, we also had access to the official records of the meetings of the Board and meetings of members; personal notes of the President of the Cooperative; Cooperative Statute; Annual Reports (1998-2010); and photos provided by the organization.

We conducted 19 semi-structured interviews with members of the Cooperative with approximate length ranging from 1.5 to 2 hours each, which were recorded and fully transcribed. To preserve confidentiality, identification of these members is not revealed (seeTable 2). The quotations used to illustrate the results were extracted directly from the interviews' records and received minor editing adjustments to eliminate grammatical errors and inappropriate language.

We also collected data through focused observation, a technique that, according Angrosino and Pérez (2000), necessarily involves interviews and is concentrated in well defined groups of activities. The observations were made in two phases of decision-making, one at each event: Informative Meeting and Deliberative Assembly. This choice was due to the importance for the study to obtain evidence on how the decision-making process occurs in the organization and how the practices adopted in this process reflect different institutional logics. We believe that the investigation of these stages of the decision-making process contributed to the analysis of the movement of identity groups that rely on different logics. 
In the event that the non-participant observation was carried out, we used a predefined script, in order to structure the observation and produce records that could be appealed during the analysis. Aiming to be less intrusive, the researcher remained quietly sitting in one of the corners of the auditorium watching and noting the events. At the end of the meetings, the researcher attended the gatherings in which there were opportunities to make inquiries about the facts and deepen issues relevant to the research. On these occasions, it was also carried out the schedule of some interviews.

Table 2 - Coding of Survey Participants

\begin{tabular}{|c|c|c|}
\hline Interview code & Group of respondents & Time in the organization \\
\hline D1 & Director & 6 years \\
\hline D2 & Director & 10 years \\
\hline G1 & Manager & 7 years \\
\hline $\mathrm{G} 2$ & Manager & 10 years \\
\hline G3 & Manager & 16 years \\
\hline CE1 & Elected cooperative member & 2 years with administrative functions \\
\hline CE2 & Elected cooperative member & 16 years with administrative functions \\
\hline CE3 & Elected cooperative member & 9 years with administrative functions \\
\hline CE4 & Elected cooperative member & 6 years with administrative functions \\
\hline CE5 & Elected cooperative member & 21 years with administrative functions \\
\hline CE6 & Elected cooperative member & 17 years with administrative functions \\
\hline CE7 & Elected cooperative member & 16 years with administrative functions \\
\hline $\mathrm{C} 1$ & Cooperative member & Partner for 22 years \\
\hline $\mathrm{C} 2$ & Cooperative member & Partner for 5 years \\
\hline $\mathrm{C} 3$ & Cooperative member & $\begin{array}{l}6 \text { years as an employee and partner for } \\
9 \text { years }\end{array}$ \\
\hline $\mathrm{C} 4$ & Cooperative member & $\begin{array}{l}6 \text { years as an employee and partner for } \\
9 \text { years }\end{array}$ \\
\hline $\mathrm{C} 5$ & Cooperative member & $\begin{array}{l}\text { Partner for } 21 \text { years. Father was } \\
\text { cooperative member }\end{array}$ \\
\hline C6 & Cooperative member & $\begin{array}{l}\text { Member for } 2 \text { years. Father was } \\
\text { cooperative member }\end{array}$ \\
\hline $\begin{array}{l}\text { Former president of } \\
\text { CAPH }\end{array}$ & Former president of CAPH & 15 years with administrative functions \\
\hline
\end{tabular}

Source: Field study 
Access to documents of the cooperative, respondents and organization of events was achieved by building the relationship between the researcher and the organization studied. With successive visits to the studied site and explanations regarding the work, gradually settling confidence. In addition to the concessions requested by the researcher to the cooperative, were carried out invitations to participate in exclusive events for members of the organization and there was access to informal gatherings taken before and after the meetings. It is worth mentioning that these informal socializing opportunities were important to obtain interviewees' reports in a less intrusive way.

The adopted type of cross-poll can be seen as a limitation. The limitation caused by the impossibility of analyzing the relationships between categories of analysis in time sequence was minimized with the adoption of mechanisms suggested by Richardson (1999) to approximate the investigation of a longitudinal perspective. Such mechanism is the formulation of the collecting material in order to provide the appearance of relevant information about past situations. One way to avoid or mitigate the memory bias is the use of documents as support in interviews, taking care not to influence the answers. Subsequently, the information collected by interviews were compared with the records in documents in order to further reduce any problems posed by recall bias.

The data processing began with the transcription of the interviews. Next, we used the Atlas TI Software for the classification of data generated by transcripts. Data were analyzed by qualitative content analysis based on historical analysis method. According to Mason, Mckenney and Copeland (1997) historical study is a descriptive report, which illuminate events, forces and personalities that triggered the detailed circumstances by the facts. So this was one of the criteria adopted in the content analysis in order to clarify the context in which decisions were taken in different periods of the cooperative history .

In the process of data analysis, we used the model of Thornton (2004), which presents the ideal types of institutional logics described in Table 1. Given the hybrid nature of cooperative organizations, as evidenced by the adoption of consistent practices and beliefs with more features an institutional environment, it was possible to relate its features with the market logic, logic of corporations and logic of State that constituted the analytical categories defined a priori. The association with such logic was verified based on the analysis of actions and decisions concerning structural changes in the studied cooperative. However, the historical analysis indicated the need to complement the categories defined

a priori, in order 
to better portray the nuances of organizational trajectory. Thus, the community and collectivist logic were added as categories in the data analysis.

This fact refers to the limits of use of ideal types, i.e., the focus only in extreme phenomena disregarding the different gradations between them. The collectivist logic of distinction and community supports, respectively, in the literature on cooperative - doctrinal system whose importance is due to the evolution of man in relation to the collectivist association - and the literature on institutional logics. Marquis and Lounsbury (2007) analyze the resistance of banking professionals to institutional change as based on community logic. The authors express that this logic involves protection of local autonomy, it implies a sense of serving the community and social interaction bounded by a network of actors that share the same physical space. The collectivist logic, in turn, refers to general human values that reflect a tendency to cooperation and compliance with the other. Adopting this reference, Gouveia et al. (2003) explain, the group of which the person is part matters more than the person himself.

The categories were analysed, moreover, by cooperative trajectory reconstitution with document analysis and semi-structured interviews and non-participant observation of how to handle the decision making today. Along the way, the three crises faced by the organization in 1952, 1986 and 1995, were identified as milestones related to decisions on structural changes under the influence of different institutional logics. We tried to identify the four proposed mechanisms by Thornton $(2004$, p. 13) by which the logics influenced the decisions of executives: $(i$ ) Meaning, adequacy and legitimacy of power sources, strategies and structures; ( $i i$ ) The perception of problems and issues to meet the control of market forces and compensation of political behavior; ( $i i i$ ) Answers and available and appropriate solutions in the control of economic forces and political activity and; (iv ) decisions on development and persistence of certain organizational structures.

\section{RESULTS AND DISCUSSION}

A review of the literature on the cooperative movement history confirms that it is correct to talk about the hybridization of institutional logics in its context: logic with social orientation (collectivist, community and State) and logic of corporation and market. During the history of the cooperative investigated, these logics are presented in different periods with distinct arrangements and balance. In Table 3, the most important events in the cooperative are presented. We discuss them in more detail during the analysis. 
Table 3 - Summary of Important Events for the CVH

\begin{tabular}{|c|c|}
\hline 1948 & $\begin{array}{l}\text { Opening cooperative based on collective farm design or Kibutz, and its guidelines of mutual aid, } \\
\text { collective work and the distribution of the profits. }\end{array}$ \\
\hline 1952-74 & $\begin{array}{l}\text { 1st Crisis in 1952. Replacing the first President of CAPH with a new cooperative's direction. } \\
\text { In } 1954 \text { begins the commercial cultivation of flowers and ornamental plants in Holambra-SP. CAPH } \\
\text { opens its flower-sales department (CAPH-Flores) firmly starting the marketing of flowers and plants. }\end{array}$ \\
\hline 1974-82 & $\begin{array}{l}\text { CAPH-Flores participation is } 34.3 \% \text { of the total volume of CAPH's transactions. The wholesale } \\
\text { distributor system takes off. }\end{array}$ \\
\hline 1982-89 & $\begin{array}{l}\text { In the mid-1980s the CAPH becomes the bigger wholesaler of flowers in the country } \\
\text { In } 1986 \text { the flower department faces difficulty to stay solvent. } \\
\text { 2nd Crisis in 1986. The balance of the CAPH's first semester was terrible. } \\
\text { Decision by the sale of wholesale business. } \\
\text { Decision by the introduction of the auction (veiling is the word for auction in Dutch) in } 1989 .\end{array}$ \\
\hline 1989-91 & $\begin{array}{l}\text { In } 1989 \text { the wholesale flower market begins. Begins also the transactions by oralauction system. The } \\
\text { flowers department takes responsibility for marketing } \\
\text { Reorganization of Multifunctional Cooperative. Decision for the conversion of CAPH's departments and } \\
\text { stores in } 13 \text { business units with some independence. } \\
\text { In } 1991 \text { CAPH-Flores recover's activities as Unidade de Negócios Veiling and assumes the management } \\
\text { of the flower market. Employment of auction analog system and in December Holambra becomes a } \\
\text { county of São Paulo }(S P) \text {. }\end{array}$ \\
\hline 1991-99 & $\begin{array}{l}\text { In } 1993 \text { starts the mediated transaction system, in parallel with the auction } \\
\text { 3rd crisis is triggered in 1995. } 10 \text { units were closed. } \\
\text { In } 1996 \text { the digital auction system is replaced by a more modern. } \\
\text { The Veiling business unit is emancipated in } 1999 \text { becoming an independent cooperative: Cooperativa } \\
\text { Veiling Holambra. }\end{array}$ \\
\hline 1999-2011 & $\begin{array}{l}\text { Division of assets is completed in } 1^{\text {st }} \text { July } 2001 \text { - official start date of the activities of CVH. From this } \\
\text { moment the CAPH is in liquidation process. } \\
\text { In } 2004 \text { the new headquarters of CVH is founded in Santo Antonio de Posse-SP. } \\
\text { In } 2006 \text { the sales of CVH exceeds the Entreposto Terminal de São Paulo, becoming the largest wholesale } \\
\text { flower market in Brazil } \\
\text { In } 2009 \text { it announced the board's decision to adopt corporate governance procedures } \\
\text { In } 2011 \text { the process of implementing corporate governance procedures starts }\end{array}$ \\
\hline
\end{tabular}
Source: Tsuboi and Tsurushima (2009) Rietjens (2003), Correa (2011), Annual Reports of CVH.

The Agricultural Cooperative Holambra (Cooperativa Agropecuária de Holambra CAPH) was founded in 1948 as part of the agreed migration project between Brazil and the Netherlands to allow the maintenance and development of the community. The initial project was coordinated by the Secretary of the Catholic Association and Dutch Farmers and 
Gardeners (KNBTB in Dutch language). At that time, Correa (2011) states that there was a belief that the absorption of young people in industry would lead to the loss of religious belief and therefore it would have motivated the association's involvement in post-war migration projects.

Under the chairmanship of Secretary of KNBTB, the cooperative had their bases in the design of collective farm or Kibutz and its guiding principles: mutual aid, collective work and the distribution of its profits. All the profit obtained by the work of the cooperative was reverted to the community, divided equitably, regardless of their financial contribution (BROEK, 2008). The community was very small and closed, standing in inhospitable region at the time it was built, which is indicative of the weight of collectivist and community logics. The implied notion in collectivist logic as Singelis et al. (1995), emphasizes the groups as a survival unit, with individuals inseparable part thereof. The group's goals are prioritized above individual goals and, in addition, it includes a tendency to cooperation and compliance with the other. In turn, the meaning expressed by the logical community as defined in Gusfield (1975), refers to a feeling of belonging to a particular area or a social structure within that area.

Supplying deficiencies during the first decades of immigration CAPH started coordinating the occupation of land and manage the location. As reported by Samenwerking (2008), the cooperative played the role of an informal town hall, organizing and structuring the basis for the infrastructure of a modern city. At this point, when the organization assumes the role of "supervising" the collective well-being, we see the orientation of State logic . This observation takes into account the characteristics proposed in Table 1 according to which, in the case of this logic, the basis of the strategies is to increase the collective good.

$\mathbf{1}^{\text {st }}$ CRISIS: In 1951, due to the difficulties in adapting to climate and topography and market opening, early crops and Dutch cattle raising frustrated the colony of immigrants. In addition to these problems, Rietjens (2003) points to the democratic and very costly administration and non-economic attitudes as direct causes of which can be considered the first crisis in the cooperative and that almost caused its premature dissolution. A comment from one member, who witnessed the events of that period, helps to understand what happened: 
The financial situation was chaotic. Mr. Heymeijer [Secretary of KNBTB] was a good person, very philanthropic. He did not understand almost anything of economy, much less in a completely foreign country, right? He went to Netherlands to make a loan and the bank there granted under certain conditions, to send someone, as IMF does now, a tutor [...]. Mr. Heymeijer thought more in the social, but when you have no money, what can you do? (CORRÊA, 2011 p. 169).

The passage describes the time it was necessary to request resources to the Dutch government to continue the project. Financial aid was sent, however, subject to a thorough evaluation by a receiver in order to ensure the sustainability of the project. This intervenor, according to Broek (2008), had a rigid business position and came with a different perspective of what was being implemented. He would later take over the presidency of the cooperative for 20 years. From this moment, said Broek (2008), the cooperative board gained a more professional environment. In the view of Rietjens (2003, p. 25): "The idealism was over". Although strongly influenced by external factors, the replacement of the President caused internal structural changes and the introduction of guidance corporation logic, which now coexist with the guidelines of logical characteristics of the cooperative movement.

At that time, one can understand that the Netherlands was in a situation of dependency with the United States, through the Marshall Plan, working for the European restructuring. Thus, the original plan of emigration, that depended financially on Netherlands, deviated its purposes, as can be seen below.

Now, Mr. Heymeijer with a collectivist ideal, asking for aid, reported to a Netherlands that was directed to capitalist exploitation, not being interesting to its government to invest in a colony that the base was the community work and the division of profits among them. Thus, to accomplish the Dutch investment, one of the requirements would have been his departure from the presidency of the Cooperative, which is now occupied by someone more in line with Dutch capitalist intentions (CORRÊA, 2011, p. 167).

With the new President, says Samenwerking (2008), significant internal changes in the Cooperative CAPH resulted in financial restructuring, diversification of products, changes in production structures, among others. The diversification of its activities has become central to the development of the cooperative. These changes indicate a deviation from the institutional logic of State for Corporate logic, with the strategies of increasing the size and diversification of the firm (see Table 1).

The commercial cultivation of flowers and ornamental plants in Holambra-SP, which later became the central activity of the cooperative, started around 1954. Since 1960, convinced of the growing demand of flowers throughout Brazil, there was support of many producers associated with CAPH who did not see before floriculture as a seriously agricultural activity. Until the middle of this decade, as Tsuboi and Tsurushima (2009) 
mention, revenues from the sale of flowers in the cooperative represented only $1-2 \%$ of total sales. In 1971, revenues from the sale of flowers exceeds for the first time, the other sectors, which made the CAPH opened in 1974 its floriculture sales department (CAPH-Flores) and, as the authors describe, initiate firmly the marketing of flowers and plants. In the mid-80s, the CAPH became the largest wholesaler of flowers in the country (TSUBOI; TSURUSHIMA, 2009).

Between 1982-85, after a restructuring, the production area of the cooperative was limited to seven points: ration mill, refrigerated slaughterhouse, egg commercialization, citrus fruit packing house, station for pig breeding, flowers and plants shed and financial sector. At this period, HAC emerged in the business world as an economic power. However, advances in the economic area, according to Rietjens (2003), were reverted to the commitment of social objectives of greater amplitude within the community. The cooperative took responsibility for the medical center, recreation areas and social club, assistance to the elderly, child care, and other social activities. We can see that in this period there was a great proportionality between the importance given on the one hand to the community and collectivist aspects and, on the other hand, to corporate and market logics.

However, over the years, the increased specialization, formalization, professionalization and reduction of social activities led to transitions in the dynamics of institutional logics. At this point, there is the third mechanism proposed by Thornton (2004, p.13) by which the logics influenced the decisions of administrators: answers and solutions are considered suitable for the control of economic forces and political activity. The professionalization, as the statements of the Directors CE6 and CE4, was a consequence of the decisions to increase in size, consistent with the corporation logic characteristics depicted in Table 1.

The cooperative was also undergoing a transformation, because it was almost a Dutch's cooperative. At the time there were many Dutch producers or Dutch descendant and the cooperative needed to grow, so luckily that, though I was on the board, and having relationships with Brazilian and Japanese producers, I could help a lot on this development and we managed to expand much in this period. (CE6)

Until 10-15 years ago, the cooperative was much more regionalist, much from the region of Holambra. So everything was closer, all much more familiar: - "oh, that's my neighbor", and soon. But the cooperative began to grow, and it started going to other regions, bringing people from other regions, beginning a miscegenation of cultures. Because once it was primarily Dutch, and they understood each other. Then the cooperative began to grow, then the management had to start being more professional. (CE4)

At this point, it is worth noting that the organization's growth strategy has taken on more importance in organizational decisions, overriding the predominant community concern in the cooperative philosophy. To grow and centralize greater quantity and variety of products 
in the organization, it was necessary to embrace new cultures and groups, even the Nikkei producers who, in a way, competed with the Dutch in the production of flowers. Therefore, it appears as the mechanism (i) proposed by Thornton (2004) of adequacy of the strategies and structures. In addition, by the CE4's interview, one can see evidence of the mechanism (ii) when the professionalization appears as an issue to meet the control of market forces. As it can be seen in Table 1, except for the first period in which the cooperative was structured with the arrival of immigrants, the growing number of cooperative occurred more sharply between 1982 and 1989, which indicates a higher weight of logic of corporation in that period and later from 1989 to 1991 in accordance with Figure 2.

Table 4 - Growth of Cooperativa Agropecuária Holambra by the Number of Cooperative Members

\begin{tabular}{l|c|c}
\hline \multicolumn{1}{l|}{ Periods } & $\begin{array}{c}\text { Change in the number of } \\
\text { cooperative members }\end{array}$ & Growth rate per period \\
\hline $1954-1964$ & $76-135$ & $77 \%$ \\
\hline $1964-1974$ & $135-140$ & $3 \%$ \\
\hline $1974-1982$ & $140-171$ & $22 \%$ \\
\hline $1982-1989$ & $171-240$ & $40 \%$ \\
\hline $1989-1991$ & $240-304$ & $27 \%$ \\
\hline $1991-1996$ & $304-295$ & -0.03 \\
\hline
\end{tabular}

Source: members' log books from CAPH.

The segment of flowers and plants grew in importance in Brazil between 1980-1985 and to respond to this, the cooperative has structured a robust wholesale distributor system. The decision to develop this structure indicates the mechanism (iii) by which corporation logic influences the executive decisions. This wholesale distributor system was composed by six warehouses (deposits) for sale in the main capitals, more than 100 lines to supply the regional market and a fleet of trucks for distribution. At the time, the number of cooperative employees increased to over 1000. Rietjens (2003) points out, however, that the system was very expensive due to inefficiencies in various links in the chain and therefore, despite the success of the business, the cooperative was facing difficulties one more time. Associated to these internal difficulties, in this period Brazil was in a serious inflationary crisis. In 1986, the country's economy was marked with the freezing of prices in the Plano Cruzado, which directly affected CAPH and made it enter the second crisis of its history.

$2^{\text {nd }}$ CRISIS: The agricultural sector at the time of the price freeze was in full harvest period and therefore had lower prices, it was severely damaged. As the cooperative functioned 
as a kind of bank transferring the funds without pledging to return, it is possible that at least part of the bank debt that it had in 1996 was contracted at that time. One can understand this when Rietjens (2003, p.54) points out that the debt of the cooperative in 1996 was $\mathrm{R} \$$ 171,470,502.64, of which R\$104,674,203.07 alone for the Banco do Brasil Bank.

With the commentary of EC7 Advisor, one can understand a little on how they worked on the financial transfer operations in the cooperative.

So, this was historic because when I arrived here in 1985 there wasn't even bank in Holambra yet. So everyone did their banking business within this cooperative office. It was all considered production advance. I had to repay my loan with production later. So who needed money, drew the money on paper because they would deliver production in three, four months. About these three months you paid the interest. [...] And the interests of financial turnover mingled with the personal interests of the cooperative (CE7).

The risk of default on the part of the cooperative greatly affected the cooperative's ability to pay off their own financial commitments, since the organization endorsed most obligations. This was a practice adopted for a long time by the cooperative in order to get around the fact that immigrants do not have Brazilian nationality, requirement for obtaining the loans.

In CAPH-Flores department, the crisis was more directly related to the failure to control the 150 vendors, who had too much power in the sales process. The balance of the first semester of the cooperative in 1987 showed terrible results, leading it to declare the bankruptcy of the CAPH-Flores department (TSUBOI; TSURUSHIMA, 2009). Given this situation, further structural changes were required, with the decision to sell the business and wholesale distributor to enter the cooperative auction system. The reported fact portrays the second and third mechanism proposed by Thornton (2004, p. 13). This event represents a milestone for the organization and is regarded as a response to the second crisis in the history of the cooperative. The CE7 Officer's testimony illustrates the situation.

\footnotetext{
Holambra began to get out of the trails because Holambra was focused upon those Calandivas (kind of flower) and then Calandiva began to disappear. From 10 million dozens, it collapsed in a matter of four years to 3 million dozens and (we) could not adapt to the new situation. This resulted, in 1987, in a nearly bankrupted the flower department. The producers talked about it to the board (of CAPH): "Now, let us solve this." Here begins the autonomy. Every year was an arm wrestling between directors and producers in the flower area, but in 1989, it resulted that we started with our auction. (CE7)
}

The above report provides insight on the active position of the cooperative and reinforces the change in assumption in the collective orientation that held the departments together. The collectivist parameter in this point begins to no longer be the CAPH cooperative to be the department of flowers. The Management Board member (CONAD) explains that the 
crisis triggered a movement to transform the units into departments. When he says "Here begins the autonomy", denotes the decisions taken and the structural changes resulting from them that were essential for the subsequent establishment of the Cooperativa Veiling Holambra.

The beginning of the activities with the auction appears as a result of the events of this period as a symbol of victory of florists-producers on the board of CAPH. In 1989, the Department of flowers starts to act as wholesale market intermediating transactions with the cooperative retailers. At the same time, the movements to dismember industries begin. The mechanism ( $i v$ ) proposed by Thornton (2004, p. 13) - development decisions and persistence of certain organizational structures - revealed at this point of the analysis, demonstrates the influence of market logic that even an incipient form, influences the decisions of responsible for the administration of the cooperative.

The decision to adopt the auction system, in response to internal pressures of cooperative members and external market pressures, resulted in significant structural changes in the cooperative. Since then, the clock or the auction has become a symbol for the cooperative. It represented mainly the entry into a new era of transparency, impartiality, professionalism and management under the aegis of the market, supply and demand laws.

In this regard, there is a fact worth mentioning. While the research in the cooperative was being held, the executive assistant was asked if he eventually had photos that could be used at this work. On that occasion, in fact, only been requested photos of the physical structure of the cooperative; but a compact disc (CD) was provided with multiple photos at different time periods. Most of the historical photos depict the evolution of the auction system (from the first auctions held orally in the cooperative to the most moderns of today) that initially had no great importance for research. However, its importance was proved central in the analysis, as the members of the cooperative had it as a symbol of the organization. As reported, the name of the flower department started to include it: veiling means auction in the Dutch language, which denotes how strong the representation element is.

Another important decision taken in the same period was the transfer of public service management, so far under the cooperative responsibility, for the first municipal administration of Holambra in 1991. The cooperative has ceased to provide services such as road maintenance, health care, education, water supply and sewage, which led to a sharp reduction in the workforce. 
Then the cooperative has begun to ... for example, the part of health, it is also disengaged. They warned everyone: "Look, we will not take care of this anymore, if you want you merge your association." And it happened. After teaching was also, they said, "Look, we will not care of school". This happened in the 1980 s and such, and said: "We will no longer take care of school, we will no longer take care of mail, we will not take care of this sort of thing". Then, in the 1980s it has detached itself many things, but it still paved the main street, still took care of the water supply. It still had many more internal things until 1995. (C5)

These changes represent a change from the collectivist and state logics. The individuals in the cooperative group now considered to be no longer an inseparable part of the organization, of which it is responsible. The characteristics of cooperation and mutual commitment are reviewed. Consistent with this, in this period, the Veiling Holambra unit interrupted technical assistance to producers.

With these events, a process of professionalization began, hiring executives with experience in non-cooperative management organizations. The discussion of professionalization in cooperatives is part of a larger discussion of business of the cooperative development that became effusive in the 1990s. The growing need to compete with noncooperative enterprises pressed cooperatives to expand their operations, either in scale or product diversification. The requirements often exceed the administrative capacity of the partners, who have to request professional managers. But some impasses emerged among the cooperative and hired executives (who came from "outside"), which caused the departure of many of the cooperative executives. In the interview fragments, one can infer the influence of logics in decisions, as emerges the mechanism of adaptation of the source of power, no longer in the hands of investors, but those who know how to manage. Furthermore, the influence of market logic can be analyzed through the perception of the structural problem, what motivated the adoption of the governance structure.

After the failure of co-management, professionals were hired from "outside" that perhaps they were good professionals, but they could not get along with the cooperative in general, and perhaps did not understand what a cooperative was, let alone the "culture of Holambra". This created serious conflicts that led to the departure of executives and/or breaking the business unit concerned. All this happened between 1990 and 1996, more or less (Former President of CAPH).

As the counselor was so involved, he thinks that he can solve it better! Then, at the time of transition, there is a difficulty, why? Because there comes a new market professional, he has a different view. A different way to solve, then there is a conflict. There is a conflict because the counselor thinks he knows ... Since he was so involved, he thinks he knows best. (CE2)

The conflict mentioned by Councelor CE2 reflects a common difficulty in Brazilian cooperatives trying to adopt separate structures of ownership and control. The specific case of $\mathrm{CAPH}$ is illustrative of the problems arising from the concentrated structure, as shown in the utterance below. 
The situation was already bad for the sake of management, of bad administration. Mismanagement of resources, mismanagement of business. The deal yielded no money, gave no profit and the staff insisted on keeping, insisted on not improve the administration or even close. To say: "No future, no income, does not generate profit, therefore terminate it". [...] The boat was going to a direction that board barely knew. [...] There was no exemption and as they were dependents, they could not - in the ordinary language - go face to face with the directors. (C5).

The management of the cooperative proved to be permeated by conflicts of interest, political movements and decisions based on favoritism and issues unrelated to the pre-set criteria.Another problem at this time, as reported in many interviews, was related to the provision of some internal bank services. In the following utterance, Counselor 5 clarifies this important event in the history of the Cooperative.

Well, each member alone was too small to take a loan. The operating cost of a loan
was too high for a single member, so the "mother" cooperative (HAC) took the
money and reissued bank notes to their members. It made a single bank note with
the bank and handed out smaller notes, and the guarantor of this operation was the
"mother" cooperative. Well, for every ten new members who took a loan, maybe six
managed to pay their bill, four did not. Who was the guarantor? The "mother"
cooperative. This, among other things, caused the bankruptcy of the cooperative.
(CE5).

The lack of control and lack of criteria that characterized such financial transactions was also present in transfers to fund units. In 1994, with the support of an international consulting firm, external and free from political influence of the cooperative, it was again held a cooperative restructuring. According to the former president of $\mathrm{CAPH}$, this support was sought in order to carry out a general realignment in the cooperative "towards the market and greater productivity." However the structural changes were not sufficient to remedy the insolvency of the cooperative in June 1995.

I started producing flowers in 1989. But at that time the cooperative was only one, was called CAPH. There was only one. This cooperative broke, this old model from the 40's or 50's, when the cooperative was founded with the immigration of the Dutch to here. In 1995 the cooperative actually exploded or imploded, I do not know which the right word is. It was the crisis of the time, just after the Plano Real, one year. Many cooperatives broke at that time. (CE5)

At this moment in Brazilian history, cooperatives, in general, have been harshly criticized for its paternalistic and not economic behavior. Therefore, many of them have reformed their social mission in order to make it consistent with principles of the market institutional logic. The interviews supported this position and expressed different levels of contestation of the orientation that based the decision making so far. This is clear, for example, when the supervisory board member comments on how the social mission in VHC currently relates to the economic purposes of the Cooperative. 
Oh, I do not see a social mission, no. I do not like these things, no. I do not think I have to have a social mission Because with social missions you think that one who is very well has to help a poor fellow. But, that I already think it's a bit socialist, you know? And I do not like it. (...) In the old days (the cooperative) supported more when Holambra was not a county and the cooperative was almost the city hall of Holambra, right? But in the end, you saw what happened right? It broke! (CE1)

$3^{\text {rd }}$ CRISIS: The almost dissolution in 1995 represented the third crisis in the history of the cooperative. In response to it, the decision to solve interference problems with the closing of ten units considered unproductive and dismemberment of the three remaining cooperatives (Flowers and Plants, Livestock and Supplies), reinforces the emphasis on efficiency and reveals evidence of the mechanism ( $i v$ ) decisions on the development of organizational structures. Therefore, the time of the division marks the move of guidance primarily by corporate logic to market logic by the cooperative leaders and other participants in the decision-making process. We can see the passage of the base of the strategies of "size increase and diversification" to "increase transaction efficiency." Models, theories, established standards and analytical market techniques have become the foundation for organizational decisions. These changes in the organization are consistent with the new institutional role, that is, a new standard reference in the field of cooperative organizations.

The transition movement guidance corporation logic to market logic is confirmed when, in 2009, the group of administrative representatives of the cooperative decided to adopt corporate governance procedures. We observe that decision, the intention of bringing the organizational actions of the economic system of capitalism investor characteristics (see Table 1), representing the market logic embodiment in the organization. However characteristic elements logic of State, as democratic participation, are still present in the cooperative, as can be seen in the reports of interviews and episodes of non-participant observation. These have identified that despite the predominance of market logic, this reference is permeated by guidelines derived from the remaining logic.

Therefore, through the data, one can highlight evidences of logic of state, collectivist and community logic concomitant to features of logic of corporation and market. By way of summary, in Figure 2 the logic that influenced the organization of the trajectory are identified in various arrangements and balances. The order in which the logics are cited, as well as the font size, indicates the prevalence on the specified date. 


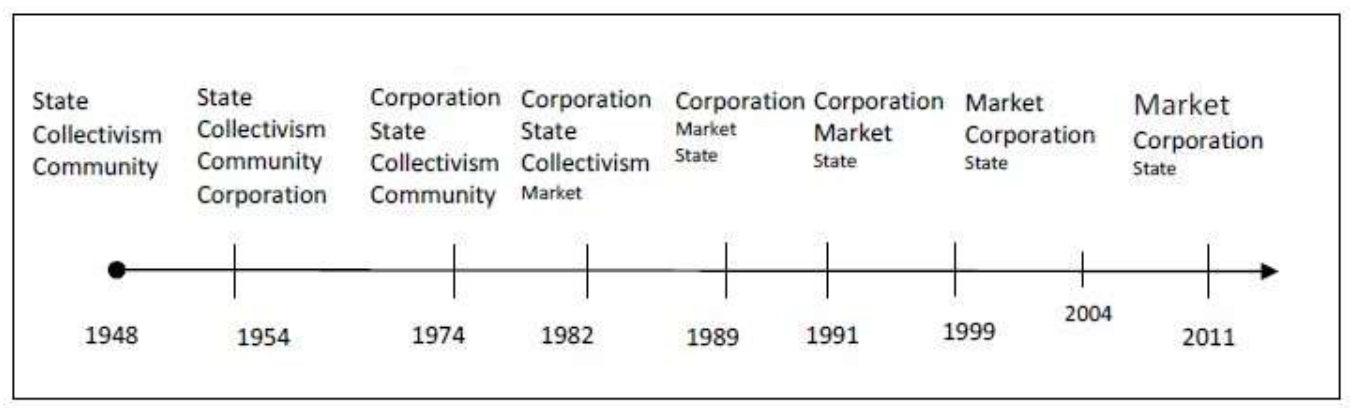

Figure 2: logical dynamics and the trajectory of CVH.

Source: Research Data

Regarding the logic of hybridity, the decision-making process of adopting corporate governance practice is illustrative of its effect. At this point of the research, it can confirm the central argument of the work of D'Aunno, Sutton and Price (1991), i.e. the "increasing penetration of inter-institutional contradictions in the daily practices of contemporary organizations." Based on the democratic participation, logic of State legitimacy source, the board of $\mathrm{CVH}$ achieved the acceptance of practice that embodies the market logic. In this case, the fusion of logic state with market logic, permeating the adoption of this practice has resulted in hybrid practice: preserved the democracy and the participation of society in decision-making, while the control and formalizing the cooperative were leveraged. It is reinforced, so the defense of institutional logics approach as not mutually exclusive and the understanding of hybridity phenomenon in organizations.

With the adoption of corporate governance practice, the tasks became clearer in the cooperative and the structure more transparent to question and/or charge the duties. With regard to the form of participation of members, the notes made by Couselor 1 and Director 2 are illustrative of the effects.

While the cooperative was small, consisted of mainly Dutch members of the community and was inside Holambra, which was very close to everyone, everyone felt belonged in the literal sense: "Oh, I can send orders to everyone, I can send orders to the director, I can send orders to the employees... ". "My product has to be like this, has to be like that." And as the cooperative grew, it became necessary said to say: "People, calm down... this is not right." If everyone come and say to the guy who pulls the cart: "Look, pull my first product" how is it going to be? Then, they began to say: "Let's make it clear how a cooperative works, what is a cooperative, what are the roles, rights and social duties, what the responsibilities are." Thus began an awareness program. (CE1)

This, I think, became clearer to them [cooperative members in general]. You know that thing of mismanagement? There was a lot of that and you know that we have almost 300 producers-members, then, is very complicated if everybody has orders, right? And when you do not know which way to follow, any one works and the result can be fully committed. So in my case, the big change I could see was that, you know? And for the company, it is essential, especially when we think a hierarchy within a cooperative. (D2) 
Considering the employment of principles of corporate governance, it is noticeable that it meets the deficiency of the definition of roles in the Cooperative. It represents the formalization of organizational processes in the Veiling Holambra Cooperative, which, according to Hall (2004), is linked to the attempt to promote the order, consistency and predictability, and therefore, efficiency. Highlighted by Lima (1998), in a functionalist perspective, organizational formalization presupposes activities guided by a series of standardized, predetermined steps; such as, it would be essential to avoid complex decision making processes, which involve loss of time in coordination.

Therefore, the decision to adopt the corporate governance principles in the cooperative reinforces the tendency to give more weight to the market logic, without eliminate elements of the State logic, which are still present in the Cooperative. The understanding that democratic participation is effective, supported by analysis of the interviews and episodes of nonparticipant observation gives strength to this remark. Despite the dominance of market logic, it is possible to identify the hybridism of logics and its effects in the Cooperative.

Relying on democratic participation, source of legitimacy of the State logic, the board of $\mathrm{VHC}$ achieved the acceptance of a practice that embodies the market logic. In this case, the fusion of State logic with market logic, permeating the adoption of this practice, has resulted in a hybrid practice: democracy and the participation of society in decision-making were preserved, while the control and formalization of the cooperative were promoted.

At least three factors were important to clarify the sequence of events in this case: $(i)$ the pressure exerted by managers hired for making changes in the structure; $(i i)$ the authority issued by the CONAD; and ( $i i i$ ) the non-ceremonial character of the formal assemblies and the participation of cooperative members in decision making. Regarding the first point, the pressure was manifested by the fear on the part of the board, that they could not keep good professionals in office since they were reported two occasions on which the directors, dissatisfied with the structure, left the administration of the cooperative. Because of this, one of the counselors had to assume this position, which required dedication in the cooperative at the expense of what was required in their particular company. Moreover, the interviewers cited several conflicts between cooperative members and managers, reinforcing dissatisfaction in the cooperative.

The CONAD authority is attributed to the fact that this was the same group that took over the cooperative in the third of CAPH's crisis, which was described as dramatic. The fact that they managed to rebuild the organization out of a chaotic situation and conducted the 
procedures to insert it into another role model, which the cooperative members believe is most appropriate with the new trends, is strongly considered. In this aspect, one can also mention that counselors are considered management models of their particular companies. It was noted during the interviews a great appreciation by the cooperative members and employees, because they started as small producers with few resources and are currently consider "successful" entrepreneurs. The third factor cited was essential to understand some of the reasons why the decision-making process occurred as described in this work.

The concern about the repercussions of adopting the governance structure in the long term implied considering the autonomy of the members in the organization. In other words, this meant involve them in the Board decision-making processes. Thus, they took two steps to propose the design changes in the governance structure. On the first step, it was noticed the intention of the Board to provide or at least present an idea of the members' effective participation in decision-making. Probably the events were organized in a way that decisionmaking is seen as democratic by the cooperative members and its adoption is not perceived as imposed, then facilitating the acceptance and consensus on decisions. The second step was deliberative and was approved by the governance structure design together with other budgets and investment proposals.

Through participant observation and interview reports, the researchers had access to decision-making situations, and provide evidence of the importance of democratic support in decision-making, demonstrating how participatory are the cooperative members at meetings, not hesitating to oppose the Board of Directors proposals. These experiences have provided better basis to comprehend the meaning of meetings for members. Democracy is of great value in decision-making, which is consistent with the rule of the State logic (presented in Table 1)that has the democratic participation as a source of legitimacy.

This finding, associated with the one that the governance structure was approved by cooperative members in the Assembly, is indicative of institutional logics hybridity in the decision-making and reinforces the claim of its influence on the adoption of corporate governance. Here, the hybridity is perceived as the mechanism through which the advisory group, supporting the interests of the executive team, introduced the practice of corporate governance consistent with market logic. This point is important because it is related to thethe question of how the hybridization mechanisms can provide variation, selection and retention of interpretive schemes. 
Unlike the fundamental change model, the thesis of hybridism of institutional logic, adopted in the present research, calls attention to the influence of the actors in the decisionmaking process, in order to accommodate changes in some aspects of behavior, without replacing the traditional identity of the organization. The incremental change is revealed, while aspects of the history and ideology of the Cooperative are preserved, reconciling themselves with the new logic. An analysis often used to explain the reconciliation of different assumptions for organizational, fundamental and incremental change, rests on models of punctuated equilibrium, which often support the understanding of institutional change in institutionalism.

Examination of drastic organizational events, such as the three crises described at the HAC Cooperative, reinforces the suitability of the punctuated equilibrium model; but relying on Farjoun (2010), the concept of duality is also present. In the view of punctuated equilibrium, practices, processes and organizational forms support change or stability; considering them as incompatible or mutually exclusive. Consequently, they should present themselves at separate times. In this study, the paradox between the two concepts is rejected, analyzing the phenomenon of hybridism as a mechanism of simultaneous change and stability.

Elements of ideology and tradition are considered "institutional remnants" that, in accordance with Dacin and Dacin (2008), have "important normative implications for the continuity of the past in defining what is considered appropriate in the present". (p. 334 , translated by the authors). This process denotes a concern for self-preservation, because, when symbolizing the aspirations of the organizational community and its sense of identity, organizations acquire greater resistance to change. However, while it takes into account the hybridism of organizational forms as a way to incite change and innovation, it is possible to understand the organizational behavior from an emphasis on duality, unlike dualism (Farjoun, 2010). In other words, the essential elements of resistance and change, stability and flexibility, preservation and innovation are considered as interdependent, mutually conditioning constituents from one another and not the opposite.

Farjoun (2010) argues that punctuated equilibrium models, when temporally separating the tension between stability and change, lose the ability to grasp the quality of these elements simultaneously. Thus, it risks letting the influence of logics hybridism go unnoticed in the decision process of the Cooperativa Veiling Holambra; it was through the renegotiation of certain structural elements, keeping others intact, that significant changes happened in the 
Cooperative history. Change occurs through the elements of stability and not despite them. Therefore, the analysis of the case presented here reinforces the assumption of duality in the renewal of organizations in which "internal and external continuities and commitments are used by organizations as anchors to introduce more drastic changes" (FARJOUN, 2010, p. 219).

\section{CONCLUSION}

The objective of this paper was to analyze the influence of the dynamics of institutional logics in decisions on structural changes adopted by an agricultural cooperative. Looking at the history of the organization and the events that followed the three moments taken as critical, the 1952, 1986 and 1995 crises, it is noted a pattern that reinforces the tendency of the organization to incorporate corporation and market logics respectively. In general, this influence has three landmarks: $(i)$ in the first crisis, with the replacement of the President of the Cooperative and the Cooperative adherence to a new management style. This change has led to the increase in size and number of business units; $(i i)$ in the second crisis, the decision by the sale of wholesale business, when the flower producers cooperative took over the marketing of the product and with the introduction of the veiling system to make the strongest sector with the management prioritizing transparency, impartiality and professionalism; ( $i i i$ ) in the third crisis, with the mobilization of actors to rebuild the Cooperative more consistent with the institutional market logic. As a result of decisions taken in the third crisis, ten business units were closed and the corporate governance model was adopted.

However, as D'Aunno, Sutton and Price (1991) suggest for hybrid organizations, conflicts in the institutional environment were identified in the structure and practices of Veiling Holambra. This study showed that the hybrid nature of institutional logics in this Cooperative manifests itself as lasting, as revealed in decision-making episodes with historical and traditional principles of democracy, equality and participation intertwined with administrative strategies for growth and increased efficiency. Data analysis showed evidences of the State logic, collectivist and communitarian logics concomitant with features of market and corporation logics. Although the market logic involves elements of democracy, equality and participation, these elements are combined with competition and economic efficiency, while according to the "cooperativist logic", the aim is cooperation and the sharing of results.

As a theoretical implication, this study showed the importance of including the sociohistorical context and the different rationales to comprehend the mechanisms of decision making processes. The contribution of the institutional logics approach is stressed with the possibility of 
an inclusive analysis of both cognitive aspects and cultural elements, the economic rationality along with other historically rooted orientations that motivate action. This analysis includes also the adoption of a historical perspective of decisions, as their study in isolation wouldn't be appropriate. Attributions of irrationality in organizations, therefore, may be considered hasty judgments, made without analytic attention.

By addressing the issue of how market logics are being combined with socially oriented logics, this research provides reflections on the hybridism of institutional logics phenomenon and analyzes its implications in a cooperative. However, its practical importance goes beyond the cooperative organizations, since the typical market companies are increasingly adopting social community behavior. This can be noticed, for instance, with the growing concern of organizations to adapt to a sustainability-oriented culture.

Based on Greenwood et al. (2011), the study matter, moreover, in order to have a better understanding in order to assist policy makers to interpret the forces that are driving behaviors in organizational contexts to thereby contribute to the design and implementation of more appropriate regulations.

Regarding the limitations of the study, although external communications have been extremely important for understanding the phenomenon studied, especially with regard to the historical context, the article denotes less consideration to internal documents, as was based only on the analysis of annual reports (1998-2010), the photos provided by the organization and the book records.

We can consider as a limit, too, the fact that the logics have been addressed in a general way by objective indicators, such as size or structural change decisions. Thus, the elements associated with meanings and justifications underlying guidance to decisions have been briefly explored, which have much to contribute to a strong inferences about institutional logic transitions and to highlight the social processes that are wrapped in these passages. As the present study not properly explored social processes, the analysis of the influence of institutional logics came through mainly inferences. Thus, it is recommended that further studies be carried out so that they can provide a better treatment for relationships between these levels of analysis. Studies based on social mechanisms as a methodological approach are especially appropriate in these situations.

Another limitation refers to the focus on the institutional logic of influences on meso level, which prevented a more systematic approach with regard to the field structure. Efforts were made to point to the societal level institutional logic that appear in the field, and through 
the literature indicate that there was a change in the logical array over time. However, a larger study, involving other organizations, can address more substantial macro level changes.

In this sense, another research topic is suggested. The study investigated the influence of logic transitions in an organization with relatively defined geographical boundaries: the Brazilian and Dutch organizations. To study how the structure of these fields influence the organization of the logics at this level and the position of $\mathrm{CVH}$ organization in the field (intermediary) reflected on diffusion of hybrid practices seems to be an interesting direction to follow. Thus, one can try to see if hybrid governance practices, as they are in the $\mathrm{CVH}$, diffuse to other Brazilian organizations, or elements and distinct behavioral dimensions can be merged. Such approaches are a promise to help report what Greenwood et al. (2011) claim to be a disputed topic, in needed of more studies: if successful variants of these configurations are diffused in the organizational field and then focus on institutional requirements.

Another suggestion regarding the opening of capital for Brazilian cooperatives which is characteristic of the logic in market investment (see Table 1). In Brazil, this practice is limited to cooperatives by legislation (5.764/71); but in the UK and Canada there are cooperatives enjoying this capitalization strategy. There are discussions in Brazil to change this law, however, for now, Bialoskorski Neto (2012) explains that the Brazilian cooperatives can benefit from the capitalization of capital market only indirectly, by creating strategic alliances with non-cooperative enterprises. Future studies may investigate how organizations are mobilizing accordingly and if the Brazilian cooperative legislation responds to this trend.

\section{REFERENCES}

ANGROSINO, M. V.; PÉREZ, K. A. M. Rethinking observation: from method to context. In: DENZIN, N. K.; LINCOLN, Y. S. (Orgs.). Handbook of qualitative research, 2. ed. London: Sage Publications, 2000. p. 673-703.

BIALOSKORSKI NETO, S. Estratégias e cooperativas agropecuárias: um ensaio analítico. 2001. In: BRAGA, M. J.; REIS, B. S. (Orgs.). Agronegócio cooperativo-reestruturação e estratégias. Viçosa: Universidade Federal de Viçosa, 2002. p. 77-97.

BIALOSKORSKI NETO, S. Economia e gestão de organizações cooperativas. 2. ed. São Paulo: Atlas, 2012.

BROEK, J. van D. Holambra_sonhos, lutas e vitórias: história de um projeto de imigração bem sucedido. Campinas-SP: Editora Setembro, 2008.

CORRÊA, A. C. P. Holambra além das flores: uma experiência de imigração holandesa. Holambra-SP: Editora Setembro, 2011. 307p. 
CRESWELL, J. W. Qualitative inquiry and research design: choosing among five approaches. Thousand Oaks: Sage, 2007.

DACIN, M. T.; DACIN, P. A. Traditions as institutionalized practice: implications for deinstitutionalization. In: GREENWOOD, R. et al. (Orgs.). The Sage handbook of organizational institutionalism. Thousand Oaks: Sage, 2008. p. 327-352.

D’AUNNO, T.; SUTTON, R. I.; PRICE, R. H. Isomorphism and external support in conflicting institutional environments: a study of drug abuse treatment units. Academy of Management Journal. v. 14, p. 636-661, 1991.

DIMAGGIO, P; POWELL, W. W. Introduction. In: POWELL, W. W.; DIMAGGIO, P (Ed.). The new institutionalism in organizational analyses. Chicago: The University of Chicago Press, p. 1-40, 1991.

FARJOUN, M. Beyond dualism: stability and change as a duality. Academy of Management Review, v. 35, n. 2, p. 202-225, 2010.

FRIEDLAND, R.; ALFORD, R.R. Bringing society back in: symbols, practices, and institutional contradictions. In: POWELL, W. W.; DIMAGGIO, P. (Eds.). The new institutionalism in organizational analysis. Chicago: University of Chicago Press, 1991. p. 232-263.

GLYNN, M. A.; LOUNSBURY, M. 'From the critics' corner: logic blending, discursive change and authencity in a cultural production system. Journal of management studies, $v$. 42, n. 5, p. 1031-1055, 2005.

GREENWOOD, R. et al. Introduction. In: . et al. (Orgs.). The Sage handbook of organizational institutionalism. Chicago: Sage, 2008. P. 99-129.

GREENWOOD, R. et al. Institutional complexity and organizational responses. The Academy of Management Annals. v. 5, n. 1, p. 317-371, 2011.

GREENWOOD, R.; SUDDABY, R.; HININGS, C.R.. Theorizing change: the role of professional associations in the transformation of institutionalized fields. Academy of Management Journal. v. 45, n. 1, p. 58-80, 2002.

GUSFIELD, J. R. The community: a critical response. New York: Harper Colophon, 1975.

JÄGER, U.; BEYES, T. Strategizing in NPOs: a case study on the practice of organizational change between social mission and economic rationale. Voluntas, v. 21, p. 82-100, 2010.

JOUTARD, P. História oral: balanço da metodologia e da produção nos últimos 25 anos. In: AMADO, J.; FERREIRA, M. M. (Coords.). Usos e abusos da historia oral. Rio de Janeiro: FGV, 2005.

KIRSCHBAUM, C. Elementos para uma teoria organizacional intraorganizacional. Perspectivas Contemporâneas-Revista eletrônica de ciências sociais aplicadas, Campo Mourão, Edição Especial, p. 5-21, out. 2010. 
KRAATZ, M. S.; BLOCK, E. S. Organizational implications of institutional pluralism. In: GREENWOOD, R. et al. (Orgs.). Handbook of organizational institutionalism. Chicago: Sage, 2008. p. 243-275.

LIMA, E.O. A formalização burocrática no contexto do ciclo de vida organizacional. Revista de Negócios, Blumenau - SC, v. 2, n.4, p. 1-10, 1998.

LOUNSBURY, M. A tale of two cities: competing logics and practice variation in the professionalizing of mutual funds. Academy of Management Journal. v. 50, p. 289-307, 2007.

MARQUIS, C.; LOUNSBURY, M. Vive la resistence: consolidation and community-level professional counter-mobilization in U.S. banking. Academy of Management Journal, v. 50, n. 4, p. 799-820, 2007.

MASON, R. O.; MCKENNEY, J. L; COPELAND, D. G. An historical method for MIS research: steps and assumptions. MIS Quarterly, v. 21, n. 3, p. 307-320, 1997.

MELO, A. Opinião: cooperativismo, um dos caminhos da terceira via. 2011. Disponível em: <http://www.ufmg.br/boletim/bol1234/pag2.html>. Acesso em: 13 de fev. 2011.

MEYER, J.; ROWAN, B. Institutionalized organizations: formal structure as myth and ceremony. American Journal of Sociology, v. 83, n. 2, p. 340-363, 1977.

NIGAM, A.; OCASIO, W. Event attention, environmental sensemaking, and change in institutional logics: an inductive analysis of the effects of public attention to Clinton's Health Care Reform Initiative. Organization Science, v. 21, n. 4, p. 823-841, 2010.

RAO, H.; MONIN, P.; DURAND, R. Institutional change in toqueville: nouvelle cuisine as an identity movement in french gastronomy. American Journal of Sociology, v. 108, n. 4, p. 795-843, 2003.

RIETJENS, J. L. A. Holambra: imigração e cooperativismo. 2003. 85f. Monografia (MBA) Departamento de Economia, Administração e Contabilidade da Universidade de São Paulo FEA USP/ Ribeirão Preto, 2003.

ROMANELLI, E.; TUSHMAN, M. L. Organizational transformation as punctuated equilibrium: an empirical test. Academy of Management Journal, v. 37, n. 5, 1994.

SAMENWERKING, G. V. Nascida para a cooperação. Revista Setembro, edição comemorativa dos 60 anos de imigração holandesa, n. 10, 2008.

SARAIVA JUNIOR, A. Esquemas interpretativos e estratégias institucionais: estudo de caso em um sistema de cooperativas de crédito. 2010. 130 f. Dissertação (Mestrado) - Centro de Pesquisa e Pós-graduação em Administração. Universidade Federal do Paraná, Curitiba, 2010.

SCHNEIDER, J.O. Democracia, participação e autonomia cooperativa. São Leopoldo-RS. Editora da Universidade do Vale do Rio dos Sinos, 1999. 
SCOTT, R.W. Institutional theory: contributing to a theoretical research program. In: SMITH, K. G.: HITT, M. A. (Eds.). Great minds in management: the process of theory development. Oxford University Press, 2004. Disponível em:

<http://icos.groups.si.umich.edu/Institutional\%20Theory\%200xford04.pdf>. Acesso em: 10 set. 2010.

SCOTT, R. W. Institutions and organizations: ideas and interests. 3. ed. Thousand Oaks, CA: Sage, 2008.

SINGELIS, T. M. et al. Horizontal and vertical dimensions of individualism and collectivism: a theoretical and measurement refinement. Cross-cultural research, v. 29, n. 3, p. 240-275, 1995.

STAKE, R. E. Case studies. In: DENZIN, N. K.; LINCOLN, Y. S. (Orgs.). Handbook of qualitative research. 2. ed. London: Sage Publications, 2000. p. 435-455.

TAYLOR, P. L. Rhetorical construction of efficiency. Sociological Forum, v. 9, n. 3, p. 459488, 1994.

TEIXEIRA, M. G. A influência do hibridismo de lógicas institucionais no processo decisório de adoção de prática de governança corporativa: o caso Cooperativa Veiling Holambra. 2012. 262 f. Tese (Doutorado) - Programa de Pós-Graduação em Administração PPGADM, Universidade Federal do Paraná (UFPR), Curitiba-PR, 2012.

THORNTON, P. H. The rise of the corporation in a craft industry: conflict and conformity in institutional logics. Academy of Management Journal. v. 45, p. 81-101, 2002.

. Markets from culture: institutional logics and organizational decisions in higher education publishing. California: Stanford University Press, 2004.

THORNTON, P. H.; JONES, C.; KURY, K. Institutional logics and institutional change: transformation in accounting, architecture, and publishing. In: JONES, C.; THORNTON, P. H. (Eds.). Research in the Sociology of Organizations, London: JAI. 2005.

THORNTON, P. H.; OCASIO, W. Institutional logics. In: GREENWOOD, R. et al. (Orgs.). The Sage handbook of organizational institutionalism. Chicago: Sage, 2008. p. 99-129.

TSUBOI, N.; TSURUSHIMA, H. Introdução à história da indústria de flores e plantas ornamentais no Brasil. Arujá-SP: Editora Lip Gráfica, 2009. 276 p.

GOUVEIA, V. V. et al. Dimensões normativas do individualismo e coletivismo: é suficiente a dicotomia pessoal vs. social? Psicologia: Reflexão e Crítica, v. 16, n. 2, p. 223-234, 2003.

VEILING HOLAMBRA. Cooperativa. Disponível em: <http://www.veiling.com.br/>. Acesso em: 27 de abr. 2011. 